\title{
Epilogue
}

\section{“Publica si domini regerent moderamina cunni”: Deciphering Queenship and Counsel}

Joanne Paul

Counsel in the early modern period - no matter the gender of the giver or receiver - was often hidden in poetry, drama or rhetorical techniques. Given the complex context of power and gender associated with queenship noted in the previous ten chapters, we should not be surprised that the authors in this volume agree that this is especially the case when counsel was given by or to queens.

As has been pointed out repeatedly in this volume, for instance by Susanna Niiranen, recovering queenly counsel often involves a process much like deciphering. This was because, as Katarzyna Kosier maintains, going beyond the prescriptions for queenly counsel could be tenuous and, indeed, dangerous. Queens often had to construct and represent themselves and their counsel as less knowledgeable, martial or capable in order to participate politically, as Catherine Fletcher shows, highlighting some of the "codes" women used in order to communicate diplomatic counsel. The focus on maintaining an outward display of loyalty and obedience means that private conciliar exchanges are, by necessity, hidden, as Helen Matheson-Pollock demonstrates in reference to Mary Tudor. This might include, as Michelle Beer, Anna Whitelock, Susan Broomhall and Alexandra Johnson show, cultural exchange, ceremony, informal influence, epistolary rhetoric and even wardrobe and architecture: all "silent advice”, which leaves few traces in written sources. In fact, John Walters suggests that this could create new ways of counselling the monarch, such as through literature. Some of this is recoverable; Hannah Coates for instance focuses on how attention to shared source material and frameworks for counsel (such as humanist readings of classical ideas like parrhesia and kairos) can help us understand conciliar relationships.

One means of discreet counsel not considered in this volume is through visual media - art, iconography and emblems. ${ }^{1}$ As Peter Daly points out, the early modern world was full of messages presented in visual symbolic form: "Over the years, tens of thousands of people will have sat in churches and chapels, and looked at the stained glass windows, or the emblematic decorations painted on stone or wood. Untold numbers of people will have pondered the emblematic decorations on the façades of buildings...”. ${ }^{2}$ Certainly, this would have been equally, if not more, true for those at the highest echelons of society, for whom almost every spoon, trinket and doorknob was elaborately decorated in symbols. ${ }^{3}$ 
These images and emblems might function as proclamations of one's lineage, standing or ambition, ${ }^{4}$ but could likewise offer counsel to the viewer. ${ }^{5}$ Most emblem books fall into the category of "moralising emblem", following from the example set by the originator of the genre, Andrea Alciato. ${ }^{6}$ Such books were often directed at "Princes, preachers, counsellors" amongst others, ${ }^{7}$ and offered "advice" on a plethora of topics. ${ }^{8}$

Importantly as well, such images could offer counsel about counsel. For instance, Alciato’s emblem “in Senatum boni Principis” illustrates the council-chamber of a good prince. This emblem is present in the first edition of Alciato's Emblematum liber in 1531, and its title and description vary little from this first presentation. The text reads:

Effigies manibus truncae ante altaria Divum,

Hic resident, quarum lumine capta prior.

Signa potestatis summae sanctique senatus,

Thebanis fuerant ista reperta viris.

Cur resident? quia mente graves decet esse quieta,

Iuridicos animo ne [sic] variare levi.

Cur sine sunt mannibus? capiant ne xaenia, nec se

Pollicitis flecti muneribusve sinant.

Caecus at est princeps, quod solis auribus, absque

Affectu constans iussa senatus agit.

[Figures without hands sit here before the altars of the gods. The chief of them is deprived of sight. These symbols of the supreme power and of the reverend senate were discovered by men of Thebes. - Why do they sit? - Because lawgivers should be serious, of a calm mind, and not change with inconstant thoughts. - Why have they no hands? - So that they may not take gifts, nor let themselves be influenced by promises or bribes. But the president is blind, because the Senate, by hearing alone, uninfluenced by feeling, impartially discharges what it is bidden to do. $]^{9}$

The text applies to lawgivers and a capta prior, later princeps, but the image is undoubtedly of a king and counsellors. Holding a sceptre and wearing a crown, the king's eyes appear to be closed, rather than obstructed, and he is relaxed, contemplative in his unadorned chair. Seated on the same level and very close to the king, on either side, are two counsellor-figures. Lacking 
hands, as the passage indicates, they still gesture to the king, working to make themselves heard in the wordless medium of the emblem. Other than the centrality and dress of the princeps, there is little difference between him and the other two figures. It is an informal scene of counsel: the king in discourse with close advisers who are seen as equals. ${ }^{10}$ As the image is reprinted (new versions of the image appear in 1534 and 1549, see Figure 1) the councilchamber becomes more formal and institutionalised, and the king elevated and blindfolded (rather than closing his eyes of his own volition). As Kevin Dunn sets out, in this emblem, "The body's capacities are divided between the figures: the senators see and deliberate but remain passive while the king sits sensorily impaired but retaining the ability to act”. ${ }^{11}$ The king is dependent on his counsellors, and it is only together that they represent a whole person: a visual representation of the "body politic" as consisting of king-in-council.

$<$ Figure 1 about here $>$

Figure 1

Andrea Alciati, “In senatum boni principis” in Opera Omnes (Basel, 1582), vol. 4, p. 1154. This is the image used in editions following the 1549 Lyons edition.

Similar images are present in other sources as well, for instance the woodcut by Richard Pynson from $15^{\text {th }}$-century England which shows a crowned monarch, seated on his throne, holding the sceptre and orb of his office. On either side are two figures who appear to be instructing the king. Four other figures range behind the king, partially obstructed by the arms of his large throne. Although the king is the central figure, and abnormally larger than the others pictured, the two counsellors are standing very close to the monarch, occupying the space in front of the throne. Like the Alciato image, by the middle of the $16^{\text {th }}$ century images of kings and their counsellors/councillors were becoming more formal with a more distinguished king. An excellent example is provided by the 1548 publication of Edward Hall's Vnion of the two noble and illustre famelies of Lancastre [and] Yorke. The frontispiece shows a picture of the newly crowned Edward VI, with seated counsellors on either side, who converse among themselves. A parallel image comes at the end of the text, of his father also in council. ${ }^{12}$

Images of queens in council are more difficult to find, as I and my co-editors discovered when seeking a cover image for this volume, and - especially in the case we did end up selecting they are even more difficult to parse. A few instances exist, most of them of Elizabeth I. She is shown in John Foxe's Actes and Monuments (1563) in an initial "C" for "Constantine”, to which the queen is compared. ${ }^{13}$ Sat on a throne, with an image of a defeated pope and the 
broken keys of St Peter beneath her feet, at her right hand are three figures, likened perhaps to the three magi, and identified by scholars as Foxe, his publisher John Day and their court agent, Thomas Norton. ${ }^{14}$ If this identification is correct, then it not only alludes to the nativity, and Constantine, but also "presentation scenes" in which books of advice are given to rulers. ${ }^{15}$ Actes and Monuments was dedicated to Elizabeth, and her identification with Constantine was as much praise as it was counsel. She is not, however, given the grand counsel scenes her brother and father were afforded. ${ }^{16}$

$<$ Figure 2 about here $>$

Figure 2

Queen Elizabeth I of England as the Emperor Constantine in initial C; John Foxe, Actes and Monuments (London, 1563), B ir

If we turn to the world of emblems, we do not fare much better. There is an emblem, from Pierre Coustau's Pegma (1555, reproduced in French in 1560) which shows a woman with a crown under a cloth of state, surrounded by speaking and gesturing female attendants, much like the "in Senatum" emblem. The subject is given as "in tempora \& mores" and the image described as "mulier imperator, \& mulier miles" or "woman emperor ${ }^{17} \&$ woman soldier". The poems that go with it give a very different image of the balanced body politic shown by the Alciato emblem. They focus on the how the "respublica" is "swamped by foolish/female wombs" 18 [fatuis subsit... vulvis] and "weak old women" [elumbes... anus]. It "trusts in foolish wombs" [Creditur... stultis... vulvis] and "insanely enjoys female command” [Foemineogue amens utitur imperio]. The "problema" it describes is "if cunts rule the public rudder/government as lords" or, "if cunts steer the ship of state as lords” [Publica si domini regerent moderamina cunni], which is why women have been banned from such rule, and given the rights of a child.

The ship of state, as a metaphor for rule, was a popular one from Plato and Aristotle onwards, and was often represented in emblems as such. ${ }^{19}$ It could also be linked directly to counsel, such as in the emblem by Achille Bocchi in his Symbolicarum quaestionum of 1574 (first published in 1555). There, the image accompanying the lesson that "Great things of counsel by support, not by strength to be governed" [Resconsilii ope, havd viribvs magnas geri], is the image of a ship. At the stern sits the "able old man” who remains "calm” and holds the tiller, 
pointing at the "youths” who scramble about. They are strong, but unable to manage the ship. ${ }^{20}$ The lesson is that calm experienced counsel, not youthful strength, ought to guide "great things”, such as the ship of state.

$<$ Figure 3 about here $>$

Figure 3

Achille Bocchi, "Resconsilii ope, havd viribvs magnas geri" in Symbolicarum quaestionum (Bologna, 1574), 213.

This emblem brings us at last to the image chosen as the cover image for this volume, the frontispiece to John Dee's Generall and Rare Memorials pertayning to the Perfect Arte of Navigation (1577), designed by Dee himself. ${ }^{21}$ The book is self-consciously a work of counsel. Dee seeks to convince the queen, by means of her Privy Council and principally one of the queen's favourites, Christopher Hatton, that a navy and empire are necessary for the security of England's shores. ${ }^{22}$ The proposal is a "Supplication to the Queen her most excellent Maiestie”, though through Hatton and the Privy Council, and divorced from Dee's own name. ${ }^{23}$ Although Dee's proposal is of interest, for its presentation as well as for its suggestion of an English "empire", it is the frontispiece - also used as the cover image for this volume - which concerns us here.

The image at the centre of the frontispiece is described as an "English Hieroglyph" and draws on a number of symbols from the occult. ${ }^{24}$ By now familiar to us, however, is the image of the ship of state to the right of the "hieroglyph". Figured as a ship of Christendom by the Chi-Rho sign $(R)$ on the masts of the ship, it is also the ship of Europe: it is identified in Greek with "EUROPA", and the image of Europa stride a bull accompanies it. ${ }^{25}$ In the ship is Elizabeth and three men, often thought to parallel the Constantine image in Actes and Monuments, which is also included as an initial "C" in General and Rare Memorials (John Day was the printer for both texts). ${ }^{26}$ Elizabeth gestures to the men with an open palm, not the pointed finger of the calm old man in Bocchi, but still appears to hold the rudder of the ship. ${ }^{27}$ It appears to be the image of a queen and her council, together steering the ship of state. As Frances Yates suggests, "Dee's virgin seeks practical advice from the traditions of the Greek empire for the defence and expansion of her realm”, which she can find in the text itself. ${ }^{28}$ Elizabeth is "advised by her sober counsellors”, according to Margery Corbett and Ronald Lightbown. ${ }^{29}$

$<$ Figure 4 about here $>$ 
Figure 4

John Dee, Generall and Rare Memorials pertayning to the Perfect Arte of Navigation (London, 1577), frontispiece.

If we look at Dee's original drawing, however, the image is slightly different. ${ }^{30}$ Still Elizabeth sits in the European ship of Christendom, reaching out with one hand with rudder clearly in the other hand. The men in the ship with her, however, have changed. There are now four, not three, marking a clear departure from the Constantine image. They are distinct, and in motion, and look to Elizabeth with arms outstretched. ${ }^{31}$ It is a scene of motion and emotion, compared to the three stationary and calm men in the printed version. It is, in other words, much closer to the Bocchi image than the initial $\mathrm{C}$, and Elizabeth is figured as the calm and experienced navigator, who may not be as strong as the youthful men that surround her, but is more sure. Looking at Dee's drawing, one cannot be as sure as Yates and Corbett and Lightbown that his intention was to show a queen advised by "sober" counsellors, instead, it seems to portray her in a position of control over her counsellors, similar to the helmsman in the Bocchi image.

Elizabeth does not point at these men, because her outstretched hand has another target: the image of occasion the near centre of the frontispiece. Occasio can be identified by her bald head and long forelock, which needs to be seized in order to win opportunity; in Dee's words "there is a Little lock of LADY OCCASION, Flickring in the Ayre, by our hands, to catch hold on" ${ }^{32}$ Occasio was no stranger to maritime presentations, in fact she is often presented upon or by the tempestuous seas. ${ }^{33}$ From the middle of the century, the famous Alciato image of Occasio also includes the image of at least one ship, apparently seeking her out. ${ }^{34}$ This is at the foundation of ideas of kairos; Aristotle had related the knowledge of particular circumstances not only to medicine, but also to navigation: "the agents themselves have to consider what is suited to the circumstances on each occasion [kairos], just as is the case with the art of medicine or of navigation”. ${ }^{35}$

Dee's Occasio indicates her forelock with her left hand, and in her right she offers a laurel wreath, symbolising victory. ${ }^{36}$ This is in contrast to the usual presentations of Occasio in which she holds a razor - as she is "keener than any cutting edge". ${ }^{37}$ Dee's Occasio is therefore already tamed, and inclined to give victory to the person who captures her. Likewise, whereas was Occasio usually shown standing on a ball or orb, here she stands with one foot on the rock above the "fortress of safety" and the other on a pyramid, perhaps symbolising prudence or the strength of the monarchy. ${ }^{38}$ The placement of Occasio on top of a pyramid, however, may also 
echo the description of the same in the Hypnerotomachia Poliphili, printed in Venice in 1499, with accompanying image. ${ }^{39}$ Notably, in the English translation of that text (in 1592), her windpushed spinning on the pyramid made a noise "as if the mynte of the Queene of England had being going there". ${ }^{40}$ It was precisely towards such an opportunity that Dee hoped Elizabeth's treasury would be headed, though there's no evidence that Dee would have seen such a translation 15 years before it was published. Alternatively (or additionally), it could be a reference to Dee himself, and the delta figure he often used to represent his own name. ${ }^{41}$

Dee's text mentions occasion and opportunity frequently, including in his explanation of the frontispiece. ${ }^{42}$ In the manuscript it is clear that Occasio looks directly at the queen, though in both versions of the image Elizabeth appears to be pointing to Occasio, indicating the direction in which her ship should travel. ${ }^{43}$ In neither version do the men on her ship look towards Occasio or her laurel wreath, their eyes are instead fixed on Elizabeth, either for guidance, or to pass on their advice.

Seizing opportunity before it flew off was something that Elizabeth's counsellors often complained she was poor at. As Hanna Coates points out in this volume, Francis Walsingham, at least once, associated this prevarication with her sex: "her Majestie beinge by sexe fearfull, cannot but be irresolute, Irresolucion beinge an ordinarie Companion to feare”. ${ }^{44}$ Elizabeth's counsellors repeatedly demonstrate a knowledge of both the notion and iconography of Occasio in their attempts to counsel the queen. ${ }^{45}$ Sir Thomas Smith writes, for instance, to William Cecil, Lord Burghley in January 1572 that "ther was never better tyme to doo good" in securing the queen's "suerty, be yt by marriage or by league”. ${ }^{46}$ As such, Burghley must "moue the quenes matie to lose no tyme, \& not to p[ro]crastinate" as she is "wont" to do. ${ }^{47} \mathrm{He}$ reminds Burghley that "Occasion the more heavy she is before, the more bald she is behend". ${ }^{48}$ Was Elizabeth truly a procrastinator? Probably she was; delay provided a useful strategy. ${ }^{49}$ Elizabeth acknowledged that "delays are dangerous", but insisted on taking the time to take advice. ${ }^{50}$ However, it must be considered that her counsellors' complaints about her predilection towards prevarication stemmed just as much from a gendered demand that she listen, and listen immediately, than simply that she was obstinate. As Susan Doran has recently suggested, the complaints of those like Burghley or Francis Walsingham in regards to her ignoring advice was rather that "Elizabeth ignored their particular 'good' counsel”. 51

Seizing Occasio was, as Walsingham's statement suggests, largely a manly affair. Emblems from the period, perhaps most notably Jean Jacques Boissard's “L'Occasion” in his Emblems 
Latins of 1588, show the naked Occasio being seized by a virile soldier. Likewise, the c. 1510 woodcut by Marcantonio Raimondi of "Virtue Dominating Fortune” shows a muscular bearded man grabbing Occasio's forelock as she stands on her spheres, and beating her naked back. So what does it mean that Dee seems to place so much stock in Elizabeth's ability to seize occasion, when even her counsellors have perhaps missed it? It could be advice very much in line with her counsellors" complaints against her, advising her to take occasion through illustrated encomia. Even so, however, it says something that in his manuscript image Dee figures her not only as the capable helmsman, but also as the one able to see and seize opportunity. Dee appears to be speaking directly to the queen in his image - counselling her to seize occasion, guide her council, and steer the ship of state herself, regardless of how her gender would regularly be thought to limit these activities. The shift in the representation of the councillors between the manuscript and print editions might be a change of heart by Dee, an intervention by Day, or indeed simply a requirement of the medium. It is almost impossible to tell.

Whether speaking of this image in particular, or the various practices and performances of counsel in the context of queenship more generally, it is clear that we, as historians, are likely to only gain access to parts of the story: indications rather than straightforward confirmations of the way in which elite women navigated the negotiations of gender and power through the giving and receiving of advice in the early modern period. Does this mean that the project is in vain? Certainly not: as this volume has attempted to show, investigating the relationship between queenship and counsel in this period challenges existing understandings of what constitutes "the political". That the advice investigated here is encoded - through symbol, performance, rhetoric, wardrobe, architecture - is itself a fascinating conclusion about the amorphous construction of the political, and the ways in which women, excluded by traditional understandings of politics, could manipulate these tools to reclaim authority in the networks of counsel which defined early modern monarchies.

Reference List:

Bath, Michael. Speaking Pictures: English Emblem Books and Renaissance Culture. London: Longman, 1994.

Bradshaw, Leah. 'Political Rule, Prudence and the "Woman Question” in Aristotle'. Canadian Journal of Political Science 24, no. 3 (1991): 557-73. 
Collinson, Patrick. 'John Foxe as Historian'. The Acts and Monuments Online. Accessed 4 $\begin{array}{ll}\text { December } & 2017 .\end{array}$ https://www.johnfoxe.org/index.php?realm=more\&gototype=\&type=essay\&book=essa y3.

Colonna, Francesco. Hypnerotomachia. Translated by R D. London, 1592.

Cooper, J. C. An Illustrated Encyclopaedia of Traditional Symbols. London: Thames and Hudson Ltd, 1979.

Corbett, Margery, and R. W. Lightbown. Comely Frontispiece: Emblematic Title-Page in England, 1550-1660. London ; Boston: Routledge \& Kegan Paul PLC, 1979.

Corgrave, Randle. A Dictionarie of the French and English Tongues. London: William Hunt, 1660.

Daly, Peter M. The Emblem in Early Modern Europe: Contributions to the Theory of the Emblem. Farnham: Routledge, 2014.

Daly, Peter Maurice. 'Emblems: An Introduction'. In Companion to Emblem Studies, edited by Peter Maurice Daly, 1-24. New York: AMS Press, 2008.

Dee, John. General and Rare Memorials Pertayning to the Perfect Arte of Navigation. London, 1577.

Deist, Rosemarie. Gender and Power: Counsellors and Their Masters in Antiquity and Medieval Courtly Romance. Heidelberg: Winter, 2003.

Dunn, Kevin. ““Action, Passion, Motion”: The Gestural Politics of Counsel in “The Spanish Tragedy”, Renaissance Drama 31 (2002): 27-60.

'Emblem: In Occasionem. Sur L’occasion.’ Alciato at Glasgow. Accessed 11 December 2017. http://www.emblems.arts.gla.ac.uk/alciato/emblem.php?id=FALc121.

Enenkel, Karl A. E. 'The Neo-Latin Emblem: Humanist Learning, Classical Antiquity, and the Virtual "Wunderkammer”, In Companion to Emblem Studies, edited by Peter Maurice Daly, 129-53. New York: AMS Press, 2008.

Evenden, Elizabeth. Patents, Pictures and Patronage: John Day and the Tudor Book Trade. Aldershot: Ashgate Publishing, Ltd., 2008. 
Forshaw, Peter J. 'The Hermetic Frontispiece: Contextualising John Dee’s Hieroglyphic Monad'. Ambix 64, no. 2 (3 April 2017): 115-39.

'French Emblems: Emblem: Principum Opes, Plebis Adminicula.' French Emblems at $\begin{array}{lllll}\text { Glasgow. } & \text { Accessed } & 4 & \text { December } & 2017 .\end{array}$ http://www.emblems.arts.gla.ac.uk/french/emblem.php?id=FJUb014.

French, Peter J. John Dee: The World of the Elizabethan Magus: The World of an Elizabethan Magus. London: Routledge, 1987.

Hoak, Dale. 'Iconography of the Crown Imperial'. In Tudor Political Culture, edited by Dale Hoak, 54-103. Cambridge; New York: Cambridge University Press, 1995.

Hunt, Alice and Anna Whitelock. Tudor Queenship: The Reigns of Mary and Elizabeth. New York: Palgrave, 2001.

Hypnerotomachia Poliphili. Venice, 1499. http://archive.org/details/hypnerotomachiap00colo.

King, John N. Tudor Royal Iconography: Literature and Art in an Age of Religious Crisis. Princeton: Princeton University Press, 1989.

Manning, John. The Emblem. London: Reaktion Books, 2002.

—. 'Whitney’s “Choice of Emblemes”: A Reassessment'. Renaissance Studies 4, no. 2 (1990): 155-200.

Stafford. Edward. 'Stafford to Burghley'. State Papers, 1588, 18 (23 November 1588): 344.

Lyly, Thomas. 'Thomas Lyly to Sir Robert Cecil'. Edited by R. A. Roberts. Calendar of the Manuscripts of the Most Hon. the Marquis of Salisbury, Preserved at Hatfield House, Hertfordshire, 1591-1595, 5 (1894): 91.

Wygant, Amy. New Directions in Emblem Studies. Librairie Droz, 1999.

Yates, Frances A. Astraea: The Imperial Theme in the Sixteenth Century. New York: Routledge, 1975.

\footnotetext{
${ }^{1}$ Visual displays in regards to clothing, ceremony and masques are considered, for instance by Beer and Whitelock. Including “emblems” in this category is problematic, for as Peter M. Daly, The Emblem in Early Modern Europe: Contributions to the Theory of the Emblem (Farnham: Routledge, 2014), 32 suggests, the emblem consisted of both image and text, and
} 
could sometimes include only the latter. For the purposes of this piece, however, emblems will be considered that consist of both text and image.

${ }^{2}$ Peter M. Daly, The Emblem in Early Modern Europe: Contributions to the Theory of the Emblem (Farnham: Routledge, 2014), 56.

${ }^{3}$ Peter Maurice Daly, “Emblems: An Introduction”, in Companion to Emblem Studies, ed. Peter Maurice Daly (AMS Press, 2008), 8-10.

${ }^{4}$ W. R. Albury, Castiglione"s Allegory: Veiled Policy in the Book of the Courtier (1528) (Burlington: Ashgate, 2014), 192.

${ }^{5}$ Daly, “Emblems: An Introduction”, 5 speaks of "the function of the emblem” being "didactic in the broadest sense: it was intended to convey knowledge and truth in a brief and compelling form that will persuade the reader and imprint itself on memory”. Karl A. E. Enenkel, "The Neo-Latin Emblem: Humanist Learning, Classical Antiquity, and the Virtual 'Wunderkammer'“, in Companion to Emblem Studies, ed. Peter Maurice Daly (New York: AMS Press, 2008), 144-5 likewise sees the emblem book as a visual commonplace book; "they offer the vast knowledge of classical and humanist scholarship in a nutshell, packed in small portions and presented in a very agreeable form”.

${ }^{6}$ Michael Bath, Speaking Pictures: English Emblem Books and Renaissance Culture (London: Longman, 1994), 2.

7 John Manning, “Whitney”s ‘Choice of Emblemes’: A Reassessment”, Renaissance Studies 4, no. 2 (1990): 185.

${ }^{8}$ John Manning, Emblem (London: Reaktion Books, 2002), 48, 148, 226, 322.

${ }^{9}$ Alciato 1531, sig. D1 ${ }^{\mathrm{v}}$. Translation provided by “In Senatum Boni Principis” Alciato at Glasglow Emblem Project (accessed 16 Aug 2011).

${ }^{10}$ This image is also used in the editions of Alciato produced in Ausburg in 1531 and 1534.

${ }^{11}$ Kevin Dunn, ““'Action, Passion, Motion”: The Gestural Politics of Counsel in 'The Spanish Tragedy’“, Renaissance Drama 31 (2002): 27.

${ }^{12}$ Metal-cut image, see Luborsky and Ingram 1998, vol. 1, p. 422.

${ }^{13}$ See Patrick Collinson, “John Foxe as Historian”, The Acts and Monuments Online, accessed 10 August 2017, https://www.johnfoxe.org/index.php?realm=more\&gototype=\&type=essay\&book=essay3 . ${ }^{14}$ Dale Hoak, “Iconography of the Crown Imperial”, in Tudor Political Culture, ed. Dale Hoak (Cambridge; New York: Cambridge University Press, 1995), 94.

${ }^{15}$ Elizabeth Evenden, Patents, Pictures and Patronage: John Day and the Tudor Book Trade (Aldershot: Ashgate Publishing, Ltd., 2008), 114. 
${ }^{16}$ There is also a mid-seventeenth-century image of Elizabeth I flanked by Cecil and Walsingham on the frontispiece of The Compleat Ambassador, containing the letters of the two pictured, amongst others, by Dudley Digges. Elizabeth, however, is not "in counsel” with the men pictured, and the book is about the counsel that goes on around her and about her, rather than any she herself is involved in. Likewise the 1693 frontispiece to the Complete Journal of the House of Lords and the House of Commons Throughout the Whole Reign of Queen Elizabeth of Glorious Memory presents Elizabeth in parliament in a similar way to the council scenes in Hall, but this is almost a full century after her death.

${ }^{17}$ Could be "general”, but the French from 1560 gives "Emperiere”, or "empress”; see Randle Corgrave, A Dictionarie of the French and English Tongues (London: William Hunt, 1660), Kk $1^{\mathrm{r}}$.

${ }^{18}$ Glasgow gives “empty” for fatuis.

${ }^{19}$ It first appears in Book VI of Plato"s Republic.

${ }^{20}$ In puppi residens clauum tenet ille quietus,/ At non quae iuuenum robora, strennuitas, /Quin multo maiora facit, melioraq[ue], solus/Ipse sua praestans omnibus ingenio./ Res magnae haus valido, aut veloci corpore siunt,/Verum animi sensu, consilio, imperio. ${ }^{21}$ This frontispiece has been analysed several times. See for instance Frances A. Yates, Astraea: The Imperial Theme in the Sixteenth Century (New York: Routledge, 1975), 49-50; Margery Corbett and R. W. Lightbown, Comely Frontispiece: Emblematic Title-Page in England, 1550-1660 (London ; Boston: Routledge \& Kegan Paul PLC, 1979), 49-56; Peter J. French, John Dee: The World of the Elizabethan Magus: The World of an Elizabethan Magus (London: Routledge, 1987), 182-7; John N. King, Tudor Royal Iconography: Literature and Art in an Age of Religious Crisis (Princeton: Princeton University Press, 1989), 238-41.

${ }^{22}$ See the context provided by Corbett and Lightbown, Comely Frontispiece, 52. For more on the contents of the book, see French, John Dee, 182-3. Notably, there is a double-sided portrait of Christopher Hatton dating to around 1580 (the information in the painting dates it to 12 December 1581), upon one side of which is an image of Tempus as Occasio, with the poem that usually accompanies the image of Occasio, ending with the instruction to hang the image in an entrance-hall, to stir up lazy men; See C. W. R. D. Moseley, “A Portrait of Sir Christopher Hatton, Erasmus and an Emblem of Alciato: Some Questions”, The Antiquaries Journal 86 (2006): 373-79.

23 John Dee, Generall and Rare Memorials pertayning to the Perfect Arte of Navigation (London, 1577), 20.

${ }^{24}$ Corbett and Lightbown, Comely Frontispiece, 49. 
${ }^{25}$ Yates, Astraea, 49; Corbett and Lightbown, 50.

${ }^{26}$ Yates, Astraea, 49 suggests that the theme of the $\mathrm{C}$ initial is expanded "to cover the theme of [Dee”s] book”. The same claim is repeated in King, Tudor Royal Iconography, 238.

${ }^{27}$ Yates, Astraea, 49. Corbett and Lightbown, Comely Frontispiece, 50 instead suggest that she holds a sceptre, not the rudder, in her left hand. In the hand-drawing, it is more clearly the rudder.

${ }^{28}$ Yates, Astraea, 50. Corbett and Lightbown, Comely Frontispiece, 50 identify the three men as "her counsellors"; French, John Dee, 184 simply as "members of the nobility”.

${ }^{29}$ Corbett and Lightbown, Comely Frontispiece, 56.

30 This drawing was catalogued amongst the drawings of Elias Ashmole and was used as a model for the frontispiece, Corbett and Lightbown, Comely Frontispiece, 51.

${ }^{31}$ As Corbett and Lightbown, Comely Frontispiece, 51 point out, whereas in the frontispiece they are "all cloaked and dressed alike", in the manuscript drawing they are more distinctive. Both she and her counsellors are also much younger.

32 John Dee, General and Rare Memorials Pertayning to the Perfect Arte of Navigation (London, 1577), 54.

${ }^{33}$ Daly, The Emblem, 99. See for instance Andrea Alciato’s Emblematum libellus (Paris, 1534), 20 - the same image appears in the 1536, 1539, 1542, and similar images of Occasio at sea appear in subsequent versions of Alciato"s influential emblem book.

${ }^{34}$ An image of Occasio at sea with a ship appears in the 1549, 1550 and 1551 Lyon editions. ${ }^{35}$ Tarik Wareh, The Theory and Practice of Life: Isocrates and the Philosophers, Hellenic Studies Series 54 (Washington, DC: Center for Hellenic Studies, 2013), 4. Aristot. Nic. Eth. 1104a.

${ }^{36}$ J. C. Cooper, An Illustrated Encyclopaedia of Traditional Symbols (London: Thames and Hudson Ltd, 1979), 96.

37 “Emblem: In Occasionem. Sur L’occasion.”, Alciato at Glasgow, accessed 11 December 2017, http://www.emblems.arts.gla.ac.uk/alciato/emblem.php?id=FALc121.

${ }^{38}$ Corbett and Lightbown, Comely Frontispiece, 56. See the pyramid emblem in Hadrianus Junius" Emblemata (1565), which describes "The Pyramids, eternal monuments of the Egyptian kings: The clinging ivy winds round them with wandering branches. The needy populace is supported by the secure wealth of its kings: And constant strength of mind flourishes for ever”; "French Emblems: Emblem: Principum Opes, Plebis Adminicula.”, French Emblems at Glasgow, accessed 4 December 2017, 
${ }^{39}$ Hypnerotomachia Poliphili (Venice, 1499),

http://archive.org/details/hypnerotomachiap00colo, b ii ${ }^{\mathrm{v}}$.

${ }^{40}$ Francesco Colonna, Hypnerotomachia, trans. R D (London, 1592), C $3^{\mathrm{r}-\mathrm{v}}$.

${ }^{41}$ Peter J. Forshaw, “The Hermetic Frontispiece: Contextualising John Dee”s Hieroglyphic Monad”, Ambix 64, no. 2 (3 April 2017): 116-17.

42 Dee, General and Rare Memorials, 53.

${ }^{43}$ Corbett and Lightbown, Comely Frontispiece, 51.

http://www.emblems.arts.gla.ac.uk/french/emblem.php?id=FJUb014. There are similar emblems and images in other emblem books of the time as well, such as Claude Paradin, Devises heroïques (1557). See Anthony John Harper and Ingrid Höpel, The GermanLanguage Emblem in Its European Context: Exchange and Transmission (Librairie Droz, 2000), 160.

${ }^{44}$ Chapter 8.

${ }^{45}$ Sir Edward Stafford, "Stafford to Burghley”, State Papers, 1588, 18 (23 November 1588): 344; Thomas Lyly, “Thomas Lyly to Sir Robert Cecil”, ed. R. A. Roberts, Calendar of the Manuscripts of the Most Hon. the Marquis of Salisbury, Preserved at Hatfield House, Hertfordshire, 1591-1595, 5 (1894): 91.

${ }^{46}$ SP $70 / 122$ f.50r.

${ }^{47}$ SP $70 / 122$ f.50r.

${ }^{48}$ SP $70 / 122$ f. $50^{\mathrm{r}}$.

${ }^{49}$ Susan Doran, Elizabeth I and Her Circle (Oxford: Oxford University Press, 2015), 274.

${ }^{50}$ Elizabeth I, Elizabeth I: Collected Works, ed. Leah S. Marcus, Janel Meuller, and Mary Beth Rose (Chicago: University of Chicago Press, 2002), 189.

${ }^{51}$ Susan Doran, "Elizabeth I and Counsel”, in The Politics of Counsel in England and Scotland, 1286-1707, ed. Jacqueline Rose (Oxford: Oxford University Press, 2017), 169. 